\title{
Hemoglobin \&Iron Levels in Normal Non-Pregnant \& Pregnant Sudanese Ladies in Khartoum State
}

\author{
Heba OB Osman ${ }^{1 *}$, Ibrahim A Ali² and Omer Abdel Aziz Musa ${ }^{2}$ \\ ${ }^{1}$ Department of Physiology, International University of Africa, Sudan \\ ${ }^{2}$ Department of Physiology, The National Ribat University, Sudan
}

Submission: October 04, 2018 ; Published: November 20, 2018

*Corresponding author: Prof Omer Abdel Aziz Musa, faculty of medicine, The National Ribat University, Khartoum Box 55, Sudan

Abstract

Background: Iron deficiency anaemia is the most common nutritional deficiency in the world. Because of the increased iron requirements of pregnancy and growth. Anaemia is considered when hemoglobin $(\mathrm{Hb})$ is less than $11 \mathrm{~g} / \mathrm{dl}$ for pregnant women. Iron deficiency anaemia during pregnancy is associated with higher rates of premature birth and low birth weight. The aim of this study is to investigate the effect of hemodilution by measuring the hematological parameters in pregnant females, by measuring Hb level, PCV and iron level.

Methods: cross-sectional study performed in Khartoum state capital of Sudan during 2018 in normal non-pregnant and pregnant Sudanese ladies in Omer Sawi hospital, The National Ribat University, Khartoum, Sudan. Ten blood samples were collected from pregnant females and ten samples from healthy women were taken as controls. Aged between 20-40.

Result: Hemoglobin value in studied population showed that out of 10 pregnant females, $10(100 \%)$ of them had normal Hb level. Iron value in studied population showed that $100 \%$ had low iron level. PCV value in studied population showed that $80 \%$ had low PCV while $20 \%$ had normal PCV.

Conclusion: According to this study the value of hemoglobin changed after applying the equation to give us a normal value compared with the value of normal non-pregnant women. This result explains the process of hemodilution that occurs in pregnant women.

Keywords: PCV; Pregnancy; Hemodilution

Abbreviatations: IDA: Iron Deficiency Anemia; HB: Hemoglobin; CDC: Centers for Disease Control; SPSS: Statistical Package for Social Science; SD: Standard Deviation

\section{Introduction}

Iron deficiency anemia (IDA) is the most common nutritional deficiency in the world; estimates suggest that 2 billion persons worldwide are iron deficient. Because of the increased iron requirements of pregnancy and growth, pregnant women and infants are recognized as the groups most vulnerable to iron deficiency anemia. The most common causes of anemia in pregnancy include iron deficiency, folate deficiency vitamin B12 deficiency, hemolytic diseases, bone marrow suppression, chronic blood loss and underlying malignancies [1]. 30-50\% of women become anemic during pregnancy, with iron deficiency being the most common form of anemia in more than $90 \%$ of the cases.' Iron is essential to all cells. Functions of iron include involvement in energy metabolism, gene regulation, cell growth and differentiation, oxygen binding and transport, muscle oxygen use and storage, enzyme reactions, neurotransmitter synthesis, and protein synthesis. Iron is absorbed primarily in the duodenum and upper jejunum, where the acidic environment keeps iron in its soluble form [2]. Iron supplements are absorbed most effectively when taken on an empty stomach.
If gastrointestinal intolerance occurs (nausea, constipation, diarrhea, abdominal pain or cramping), taking the supplements with food or at bedtime may alleviate these symptom. Iron deficiency anemia is characterized by a defect in hemoglobin synthesis, resulting in red blood cells that are abnormally small (microcytic) and contain a decreased amount of hemoglobin (hypochromic) [3].

Iron deficiency anemia can result from inadequate iron intake; decreased iron absorption, increased iron demand, and increased iron loss [4]. Approximately $800 \mathrm{mg}$ of iron are required in pregnancy, over and above the $230 \mathrm{mg}$ of Iron that the women would have required even if she had not been pregnant, and the $150 \mathrm{mg}$ that she may lose through blood loss at delivery $[5,6]$.

As iron requirements during pregnancy increases they form a particularly susceptible group especially in developing countries and affects up to $52 \%$ of pregnant women [7]. Centers for Disease Control and Prevention (CDC) has defined anemia in pregnancy as 
hemoglobin $(\mathrm{Hb})$ level of less than $11 \mathrm{~g} / \mathrm{dL}$ during the $\mathrm{I}^{\mathrm{st}}$ and $\mathrm{III}^{\mathrm{rd}}$ trimesters and less than $10.5 \mathrm{~g} / \mathrm{dL}$ during the II $^{\text {nd }}$ trimester $[8,9]$.

IDA during pregnancy is associated with higher rates of premature and low birth weight [10]. The lower hemoglobin cut-off is due to haemodilution in pregnancy as plasma volume expands up to $30-40 \%$ as compared to $20-25 \%$ increase in red cell mass [11]. Ferritin reflects iron stores and is the most accurate test to diagnose iron deficiency anemia [12-14]. It is also an acute phase reactant and can be elevated in patients with chronic inflammation or infection.

The overall iron requirement during pregnancy is significantly greater than that in the non-pregnant state despite the temporary respite from iron losses incurred during menstruation. Iron requirement increase notably during the second half of pregnancy because of the expansion of the red blood cell mass and the transfer of increasing amount of iron to both the growing fetus and the placental structures [15].

Approximately $65 \%$ of the stored iron is in the circulating red cells in the adult women, additional iron stores located in the bone marrow, liver and spleen in the form of ferritin. The first pathologic changes to occur in iron-deficiency anemia is the depletion of iron stores in the bone marrow, liver and spleen, resulting in a depressed serum ferritin level, the serum iron level falls [16]. During pregnancy, haemodilution leads to reduced hemoglobin concentration, whereas both serum iron and ferritin concentration decrease and total iron-binding capacity increases [17]. This results in dilutional drop in Hb concentration creating a low viscosity state facilitating oxygen transport to the tissues including placenta.

The prevalence of iron deficiency anemia in developing countries is $52 \%$ [18]. It has decreased in the developed countries over the past several decades and this has been variously attributed to iron fortification, prophylactic iron supplements, better health care and public health programs aimed at women and children [19]. For diagnosis of IDA in pregnancy ferritin level $<12 \mu \mathrm{g} / \mathrm{L}$ is considered as the gold standard [20] Serum iron can be normal or high if the pregnant female is on oral iron even with IDA [21] The serum iron Values 40-155 $\mu \mathrm{g} / \mathrm{dl}$ [22].

The estimation of ferritin is expensive and cannot be routinely done in all cases especially in developing countries. As the blood volume can increase by up to $1.5 \mathrm{~L}$ then the actual haemodilution should be considered in anemia diagnosis and iron level can also be affected by this increased volume. This pilot study was designed to investigate the level of $\mathrm{Hb}$ and iron in pregnancy in relation to the PCV as an indicator of hemodilution.

\section{Methods}

This is an analytical, cross-sectional study performed in Khartoum state capital of Sudan during 2018 in normal and pregnant Sudanese ladies in Omer Sawi hospital, The National Ribat University, Khartoum, Sudan. A total number of 20 ladies were included, 10 healthy pregnant subjects aged between 20-40 years and 10 non pregnant. All pregnant subjects were selected randomly during their antenatal visits. Ethical Approval of this study was obtained from the National Ribat University NRU.

The objectives of the study were explained to all individuals participating in the study. Questionnaire interviews with all participants were done covering information about age, pregnancy number, pregnancy stage, iron and folic acid intake. A five $\mathrm{ml}$ of blood sample was collected in EDTA for Hb, PCV and iron level.

$\mathrm{Hb}$,PCV and Iron levels were measured using COBAS INTEGRA $400 \mathrm{plus} \mathrm{ug} / \mathrm{dl}$. All the data collected in this study were analyzed using the statistical package for social Science (SPSS) computer program version 20. Data were expressed as means with standard deviation(SD). $\mathrm{P} \leq 0.05$ was considered statistically significant.

After obtaining the result, we applied a calculation of the haemoglobin and iron parameter by this law:-

Hb x plasma - Normal Pcv

Iron x plasma - Normal Pcv

\section{Result}

The study was carried out on ten normal pregnant women, four in the second trimester and sex in the third trimester and the values were compared with ten non pregnant women were taken as control.

In this study we have three groups:-

- Group 1 values for ten pregnant women

- $\quad$ Group 2 values for ten pregnant women after application the equation.

- $\quad$ Group 3 values for ten non pregnant women (control)

Table 1: Hemoglobin in pregnant and normal women.

\begin{tabular}{|c|c|c|c|c|c|}
\hline & $\mathbf{N}$ & Mean & T value & P. value & \\
\hline Group 1 & 10 & $11.65 \pm 0.67$ & \multirow{2}{*}{3.557} & \multirow{2}{*}{0.002} & \multirow{2}{*}{ Significant } \\
\hline Group 2 & 10 & $14.45 \pm 0.40$ & & & \\
\hline Group 1 & 10 & $11.65 \pm 0.67$ & \multirow{2}{*}{24.77} & \multirow{2}{*}{0} & \multirow{2}{*}{ Significant } \\
\hline Group 3 & 10 & $38.56 \pm 0.87$ & & & \\
\hline Group 2 & 10 & $14.45 \pm 0.40$ & \multirow{2}{*}{26.079} & \multirow{2}{*}{0} & \multirow{2}{*}{ Significant } \\
\hline Group 3 & 10 & $38.56 \pm 0.87$ & & & \\
\hline
\end{tabular}

Table 2: Iron in pregnant and normal women.

\begin{tabular}{|c|c|c|c|c|c|}
\hline & $\mathbf{N}$ & Mean & T value & P. value & \\
\hline Group 1 & 10 & $17.90 \pm 0.86$ & \multirow{2}{*}{4.292} & \multirow{2}{*}{0} & \multirow{2}{*}{ Significant } \\
\hline Group 2 & 10 & $22.25 \pm 0.53$ & & & \\
\hline Group 1 & 10 & $17.90 \pm 0.86$ & \multirow{2}{*}{2.539} & \multirow{2}{*}{0.021} & \multirow{2}{*}{ Significant } \\
\hline Group 3 & 10 & $14.89 \pm 0.80$ & & & \\
\hline Group 2 & 10 & $22.25 \pm 0.53$ & \multirow{2}{*}{7.783} & \multirow{2}{*}{0} & \multirow{2}{*}{ Significant } \\
\hline Group 3 & 10 & $14.89 \pm 0.80$ & & & \\
\hline
\end{tabular}

The $\mathrm{Hb}$ measurement as mean $\pm \mathrm{SD}$ were taken and were found significantly lower than the normal value for all. Table 1 The 
mean of $\mathrm{Hb}$ is $11.65 \pm 0.67,14.45 \pm 0.40,38.56 \pm 0.87$ in group 1,2 and 3 respectively. Figure 1 There was significant difference. The Iron $\mathrm{Hb}$ measurement as mean $\pm \mathrm{SD}$ were taken and were found significantly lower than the normal value for all. Table 2 The mean of Iron $17.90 \pm 0.86,22.25 \pm 0.53,14.89 \pm 0.80$ in group 1,2 and 3 respectively. Figure 2 There was significant difference.

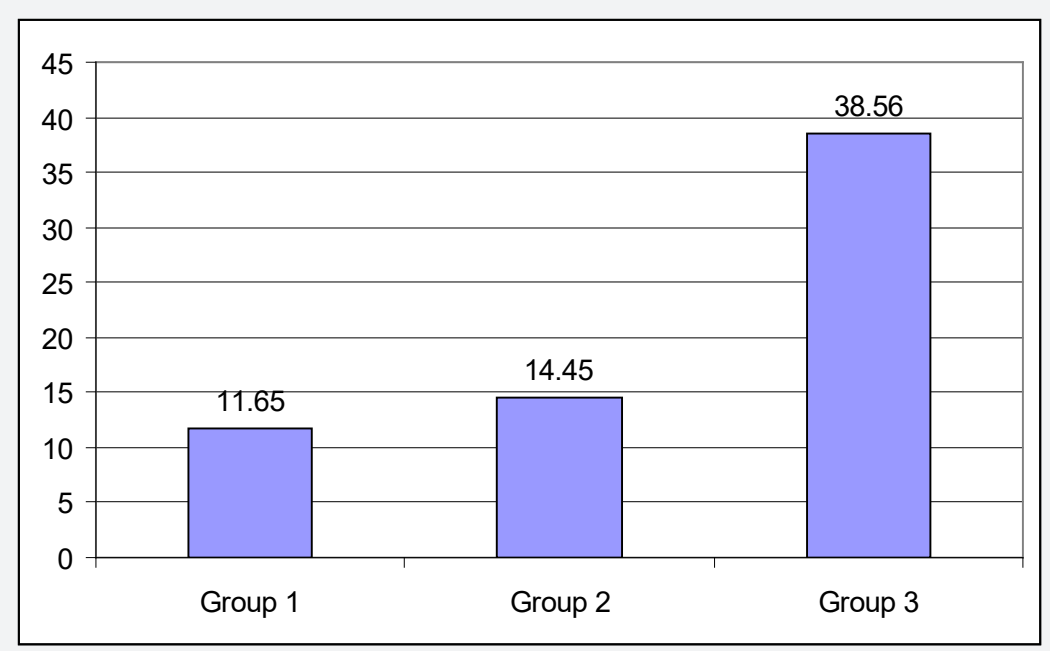

Figure 1: Haemoglobin in pregnant and normal women.

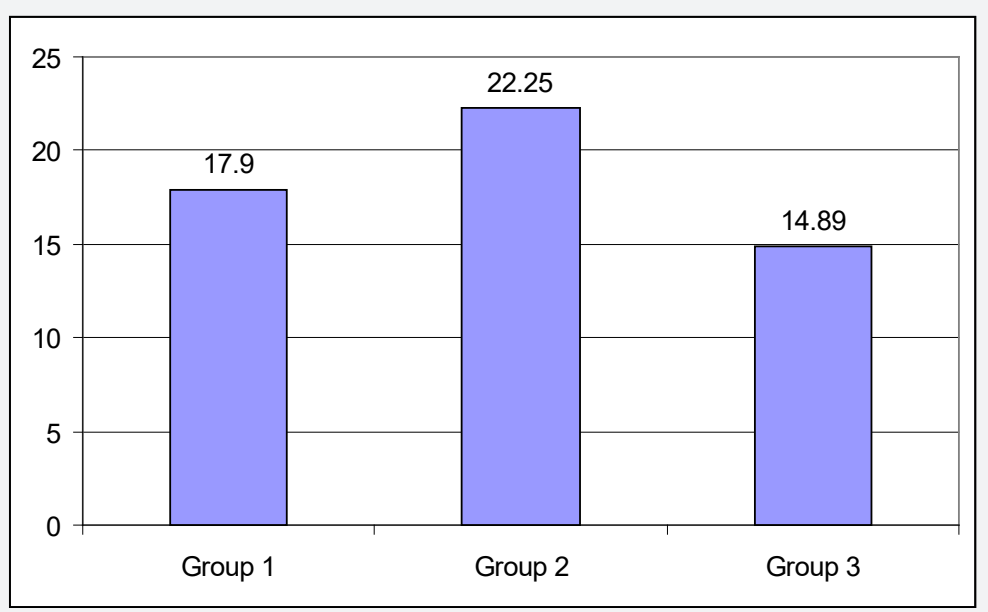

Figure 2: Iron in pregnant and normal women.

\section{Discussion}

Hemoglobin concentration and hematocrit, because of their low cost and quick assessment, are most commonly used to screen for iron deficiency; these measures reflect the amount of functional iron in the body. Iron deficiency anemia in pregnancy is an important preventable cause of maternal and perinatal morbidity and mortality.

Anemia in pregnancy has been defined by criteria from the Centers for Disease Control and Prevention (CDC) as a hemoglobin level of less than $11 \mathrm{~g} / \mathrm{dL}$ during the first and third trimesters and less than $10.5 \mathrm{~g} / \mathrm{dL}$ during the second trimester. In this study mean hemoglobin level was more than $11 \mathrm{gm} / \mathrm{dl}$ in test group after applied the equation, this result explains the process of hemodilution that occurs in pregnant women.

Two pregnant women have normal PCV and eight of them have normal PCV. Low serum iron was found in all pregnant women. Iron transfer from mother to fetus occurs against the concentra- tion gradient. Most iron transfer to the fetus occurs after 30 weeks of gestation which correspond to the time of peak efficiency of maternal iron absorption.

\section{References}

1. Allen LH (2000) Anaemia and iron deficiency: effects on pregnancy outcome. AM J Clin Nnutr 71 (5 Suppl): 1280S-1284S.

2. (1998) Recommendations to prevent and control iron deficiency in the United States. Centers for Disease Control and Prevention. MMWR Recomm Rep 47(RR-3): 1-29.

3. Provan D (1999) Mechanisms and management of iron deficiency anaemia. Br J Haematol 105 (Suppl1): 19-26.

4. Irwin JI, Kirchner JT (2001) Worldwide Prevalence of Anaemia 19932005. Geneva, Switzerland: World Health Organization; 2008. Am Fam Physician 84: 1379-1386.

5. Bothwell TH (2000) Iron requirements in pregnancy and strategies to meet them. Am J clin Nutr 72(1 Suppl): 265S-271S.

6. Bender DA (2003) Do we really know vitamin and mineral requirement, for infants and children? J R Soc Promot health 123(3): 154-158. 
7. Tiwari M, Kotwal J, Kotwal A, Mishra P, Dutta V, et al. (2013) Correlation of hemoglobin and red cell indices with serum ferritin in Indian women in second and third trimester of pregnancy. Med J Armed Forces India 69(1): 31-36.

8. Centers for Disease Control (1989) Criteria for anemia in children and childbearing-aged women. MMWR Morb Mortal Wkly Rep 38(22): 400-404.

9. Abdelgader EA, Diab TA, Kordofani AA, Sana EA (2014) Hemoglobin level, RBCs Indices, and iron status in pregnant females in Sudan. Basic Research Journal of Medicine and Clinical Science 3(2): 08-13.

10. Rigvardhan, Vinod Raghav, Rakhi Negi, Punyashlok Biswal, YS Rana, et al. (2016) Correlation of serum ferritin with red cell indices and hemoglobin in indian women in second and third trimester of pregnancy. International Journal of Contemporary Medical Research 3(10): 3069-3072.

11. Goddard AF, James MW, McIntyre AS, Scott BB, British Society of Gastroenterology, et al. (2011) Guidelines for the management of iron deficiency anaemia. Gut 60(10): 1309-1316.

12. Matthew WS, Jason ED (2013) Iron Deficiency Anemia: Evaluation and Management. American Academy of Family Physicians 87(2): 98-104.

13. Sana EA, Abdelgader EA, Tayseer AD, Omer LM, Kordofani AA, et al. (2013) Merit Iron deficiency anaemia in pregnancy and the new born child. Research Journal of Microbiology and Biological Sciences 1(2): 021-029.

14. Abdelgader EA, Tayseer AD, Kordofani AA, Sana EA (2014) Haemoglobnin level, RBCs Indices, and iron status in pregnant females

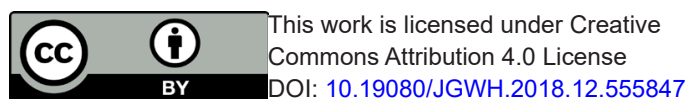

in Sudan. Basic Research Journal of Medicine and Clinical Science 3(2): 08-13.

15. Hallberg L, Hulten L (1996) iron requirements, iron balance and iron deficiency in menstruating and pregnant women. In: Halberg L, Asp Ng (eds. ), Iron nutrition in health and disease. George Libby, London, UK, pp. $165-182$.

16. Carriaga MT, Skikne BS, Finely B, Cutler B, Cook JD, et al. (1991) Serum transferring receptor for the detection of iron deficiency in pregnancy. Am J Clin Nutr 54(6): 1077-1081.

17. WHO Scientific group (1968) Nutritional anaemias. Report of a WHO scientific group 405: 5-37.

18. Scholl TO, Hediger ML (1994) Anaemia and iron deficiency anaemia: compilation of data on pregnancy outcome. Am J Clin Nutr 59(2 Suppl): 482S-501S

19. Sana EA, Abdelgader EA, Tayseer AD, Omer LM, Kordofani M, et al. (2013) Iron deficiency anaemia in pregnancy and the new born child. Research Journal of Microbiology and Biological Sciences 1(2): 021029.

20. Crichton RR (1992) The biochemistry of ferritin. Br J Haematol 24(6): 677-681.

21. Abbassi-Ghanavati M, Greer LG, Gunningham FG (2009) Pregnancy and laboratory studies: a reference table for clinicians. Obstet Gynecol 114(6): 1326-1331.

22. Broek VDNR, Letsky EA (2000) Etiology of anemia in pregnancy in south Malawi. Am J Clin Nutr 72(1 suppl): 247S-256S.

\begin{tabular}{l} 
Your next submission with Juniper Publishers \\
will reach you the below assets \\
- Quality Editorial service \\
- Swift Peer Review \\
- Reprints availability \\
- E-prints Service \\
- Manuscript Podcast for convenient understanding \\
- Global attainment for your research \\
- Manuscript accessibility in different formats \\
( Pdf, E-pub, Full Text, Audio) \\
- Unceasing customer service \\
Track the below URL for one-step submission \\
https://juniperpublishers.com/online-submission.php \\
\hline
\end{tabular}

